\title{
FATHOM
}

\section{The letter that vivifies in Hardy's texts}

La lettre qui vivifie dans les textes de Thomas Hardy

\section{Annie Ramel}

\section{OpenEdition}

\section{Journals}

Electronic version

URL: http://journals.openedition.org/fathom/139

DOI: 10.4000/fathom.139

ISSN: 2270-6798

\section{Publisher}

Association française sur les études sur Thomas Hardy

\section{Electronic reference}

Annie Ramel, «The letter that vivifies in Hardy's texts », FATHOM [Online], 1 | 2013, Online since 17 May 2013, connection on 02 May 2019. URL : http://journals.openedition.org/fathom/139; DOI : 10.4000/ fathom.139

This text was automatically generated on 2 May 2019. 


\title{
The letter that vivifies in Hardy's texts
}

\author{
La lettre qui vivifie dans les textes de Thomas Hardy
}

\section{Annie Ramel}

1 The epigraph to Jude the Obscure announces that "the letter killeth". If we take the word "letter" as meaning "a missive", the relevance of the statement to the diegetic world of Hardy's fiction appears striking. In Tess of the d'Urbervilles, the horse of the d'Urbervilles, Prince, is killed by a collision with the mailcart carrying letters, as Annie Escuret has judiciously pointed out (Escuret 1983, 582). The death of the animal, "the breadwinner" of the d'Urbervilles, will spell disaster for Tess, who will have to look for another "breadwinner" for her family. This scene is echoed by an episode near the end of the novel, when Angel (after re-reading Tess's impassioned letter) is looking for his wife in Sandbourne: not knowing her address, he goes to the central post-office and, as postmen are coming out with letters for the morning delivery, he is given the address of Tess's lodging-house. He is now on his way to disaster: the end of the chapter will show him colliding headfirst with a truth that will destroy both him and Tess. A hit or a miss: the course followed by letters in Hardy's novels ends either in violent collision, or in awkward failure. Indeed there are innumerable examples of letters that miss their targets 1 - intercepted, purloined letters, letters that go astray and never reach their addressees, letters that are never written, letters that are read/written too late, or too soon. Intersubjective communication always dysfunctions in the world of tragedy, thus leading the characters onwards to their doom. Every one has in mind the letter to Angel containing Tess's confession, which will never reach its addressee owing to its having been mistakenly thrust under the carpet. Or the letter from Angel that Tess was so desperately yearning for at Flintcombe Ash (Hardy 1988, 287), and which never came: all she got was some writing in blood on a crumpled piece of paper, "a piece of blood-stained paper, caught up from some meat-buyer's dust-heap" which was beating up and down the road without the gate of Parson Clare's vicarage $\left(289^{2}\right)$.

2 In The Mayor of Casterbridge too, letters wrongly used bring disaster: Henchard becomes estranged from Elizabeth-Jane because of his untimely reading of a letter that reveals she 
is not his daughter. The love-letters that Lucetta once wrote to Henchard turn into "oral poison" when Henchard reads them aloud to Farfrae (Lucetta's husband) while Lucetta hears every word of them from another room, standing transfixed as she awaits the moment when the signature shall be read, and her past conduct revealed to her husband - but Henchard relents and stops short of disclosing her secret. The letters however will be read aloud to a boisterous crowd in Mixen Lane, for Henchard has entrusted the badly sealed bundle to Jopp, his worst enemy, not knowing that he meant to take revenge on him. Thus Lucetta will be killed by her own letters, as the populace organize a "skimmity-ride" to bring scandal upon the couple, and she dies of a fit.

The letter as "grapheme" also kills in the diegesis of Hardy's novels. The letter "C" formed by the fat enclosing John Durbeyfield's heart reads like his fate written on his flesh: its turning into a complete circle (an "O") will spell death for him (Hardy 1988, 26). The fiery letters painted in red by a religious fanatic on a wall and a stile enter Tess "with accusatory horror" as though they were knives thrust into her heart ("that word was driven well home to the reader's heart" 85). They are horrible, says Tess, "crushing, killing" (85). The "tex" (which the man claims he believes in as much as in his "own existence" 85 ) seems to be painted on Tess's body, for the stile-boards send back to Tess a mirror-image of herself: Tess stands in shock looking at the "staring vermilion words", the "fiery lettering" causes "a sudden flush" to appear on her face, the boards have undergone a "hideous defacement" and the wall exhibits "a strange and unwonted mien". The "nice bit of blank wall" recalls the end of the previous chapter, where Tess's body deflowered by Alec is evoked as a "beautiful feminine tissue, sensitive as gossamer, and practically blank as snow as yet" (77, my italic). That Tess falls a victim to the letter has already been argued $^{3}$. To that analysis I wish to add my own interpretation: in this novel, tragedy is not caused by culture interfering with nature (which, if left untampered with, would make for universal welfare), but by a deficiency in culture itself - a flaw in the Symbolic order, in the function that Lacan has called the Name of the Father (or the paternal metaphor $\left.{ }^{4}\right)$. When Tess's body turns into a "tex", it means a deadly confusion between human bodies and systems of textuality (in Lacanian terms, between the Real and the Symbolic): bodies have become "intextuated", to use a phrase coined by Michel de Certeau. When stiletto-like words are thrust into people's hearts, the signifier becomes incarnated in human flesh. Normally, the metaphoric function of language puts a bar between the signifier and the signified, between the sign and its referent. It draws a line between things and words, between nature and culture. Because any object represented by language is by necessity "the flower absent from all real bouquets", the Thing (Das Ding ) is kept at bay, and jouissance is prohibited. Not so in the world of tragedy, where the word is made flesh. The writing on Tess's "beautiful feminine tissue" may be a metaphor in Hardy's text, but in the diegesis it means that the heroine is "brutally pierced" (Tanner 186) by the pen/penis of Alec d'Urberville. The red letters "driven home" to Tess's heart foreshadow the "gigantic ace of hearts" that appears on Mrs Brooks's ceiling, read as a sign that Alec d'Urberville has been stabbed to death in the room above ("the point of the blade had touched the heart of the victim" 370): Alec's heart has become "intextuated", the distinction between the literal and the figurative meaning of the word "heart" is annulled. We understand now that Tess's "trump card" is not to be understood in a figurative sense (as we thought it was when Mrs Durbeyfield said her daughter should play "her trump card aright", and Jack Durbeyfield ventured that Tess's trump card might be "her d'Urberville blood" 55), but in a literal sense: Tess's "d'Urberville blood" is not the symbolic "blue" blood inherited from her aristocratic ancestors, but the real 
blood of Alec d'Urberville turned into a "tex", a writing in blood imprinted on the ceiling 5 . The scene serves as a counterpoint to the passage in which Alec d'Urberville "writes" on Tess's body.

4 The Mayor of Casterbridge is basically the tragic story of a man who offers to sell his wife like a mare at a fair and is taken at his word: Susan had warned her husband that his "joke" might be made too often and carried too far (Hardy 1987, 11), and Henchard will later regret "that his wife had taken him so literally" (18, my italic). The theme of jokes that are in fact "practical" jokes because they are played for real is a recurrent theme in the novel: Henchard forces the choir to play David's Psalm at the Three Mariners, and means the prophecy for his enemy Farfrae (the performer on the clarionet is horrified when he realizes that "'twas meant for a living man" 234); Elizabeth-Jane fears the worst after this scene when Henchard tells her that he is a man to his word, "a frightful practical joker" when he chooses (235). The attempted murder of Farfrae by Henchard is "some practical joke" played on him (239), Henchard's reading of Lucetta's letters to her husband is "only a sort of practical joke" (251), the skimmity-ride is "a great jocular plot" (268) - a joke that will kill Lucetta. Henchard's lie to Newson about his daughter's death is unintentional, an unpremeditated "fabrication" which he had expected the sailor to "unmask" in five minutes (293). Yet Newson believes it, and departs immediately, asking no questions. Later, he will look upon the incident as a joke that was played on him ("Ha - ha - 'twas a good joke, and well carried out" 316), a light-hearted view which Elizabeth-Jane rejects indignantly (“"a joke? - 0 no!' she cried" 316). Henchard is but "a gamester" (327) whose jokes are always taken in earnest. For the world of tragedy allows of no free play, no flicker of meaning between signifier and signified, sign and referent, no metaphoric disparity between tenor and vehicle. For instance the phrase "unprincipled bread" is a metaphor that has lost its metaphoric quality: the bread is "unprincipled" because those who participated in its making (among them the "cornfactor" who sold his wife at Weydon Priors) are "unprincipled". But the expression ceases to be a true metaphor when the moral judgement it implies materializes in the concrete reality of things: when Henchard's distasteful behaviour results in the production of bread that is literally distasteful.

5 An excess of meaning characterizes the experience of the tragic character in Hardy's fiction. The biblical slogans painted in red on the wall are meant for Tess, unmistakably; they inscribe on the "blank" page of her body the Other's knowledge about her fault, and to make sure that meaning is properly conveyed to the reader's heart, the words are hammered in by means of commas placed after each word ("placing a comma after each word, as if to give pause while that word was driven well home to the reader's heart", Hardy 1988, 85). In Lacanian terms, that parodic punctuation, which actually bores holes into the reader's heart, may be understood as a sort of "quilting" operation gone mad - the "quilting-points" being those points in discourse at which the signified and the signifier are knotted together, not on a one-to-one basis (as in Saussure's view), but by a retroactive effect; for according to Lacan the signified is constantly sliding under the signifier, and the function of the "quilting-points" is to put a halt to what otherwise would be an endless slippage. In the biblical slogan painted in red, the free flow of language is arrested in a coagulation that conflates the signifier (the red letters), the signified (the idea of sin), and the referent (Tess's "sinful" body) in a solid mass, the commas making the slippage of meaning impossible. There is no escaping the meaning of the words that an omniscient Other paints in glaring red letters for Tess to read. 
This is where the literary letter comes in useful: for where the staring vermilion words "shout themselves out", where the voice of a knowing Other drives home its cruel messages, the literary letter restores a form of silence and turns meaning into something shifting, uncertain, problematic. It is at this point that that the "crushing, killing" letter may turn into a letter that vivifies, that the death-drive may be reversed into a life-drive ${ }^{6}$. For instance, the "sticky blights" that make "madder stains" on Tess's skin in the garden at Talbothays (127) are another occurrence of the motif of the red stain, the "scarlet letter" that brands Tess as a fallen woman. Here too the visual space is saturated by meaning, here too nature and culture are conjoined - for the signifier "blight" refers both to the real stain on Tess's arm, and to the moral blemish of sin (Tess has experienced a "corporeal blight" when she was seduced by Alec, 129). But at this point the text grows remarkably poetical, with innumerable alliterations, consonances and assonances:

She went stealthily as a cat through this profusion of growth, gathering cuckoospittle on her skirts, cracking snails that were underfoot, staining her hands with thistle-milk and slug-slime, and rubbing off upon her naked arms sticky blights which, though snow-white on the apple-tree trunks, made madder stains on her skin. (127)

7 The letters that insist here form chains, both graphic and phonemic: the vowel "o" ("profusion", "growth", "cuckoo", "underfoot"), the vowel "a" ("stealthily", "cat", "gathering”, “cracking”, "snails", "staining”, “naked arms", “apple”, “made madder stains"), the consonant /s/ ("stealthily", "spittle", "skirts", "snails", "staining", "slugslime", "sticky", "skin"), the consonant /th/ ("stealthily", "through", "growth", "thistle"), the consonant /k/ ("cat", "cuckoo", "skirt", "cracking", "milk", "naked", "sticky", "trunks", "skin"), the consonant /1/ ("stealthily", "spittle", "snails", "thistlemilk and slug-slime", "blights", "apple"), the consonant "m" ("milk", "slime", "arms", "made madder"), etc.

8 In the play of poetics, our attention is drawn towards the material part of the signifier: "it is as if the signifier lost touch with the signified, and stood there like a silent cipher" (Paccaud-Huguet 287). For according to Lacan the signifier has two faces: one for meaning, and one for jouissance. The letter is that face of the signifier which is loaded with the affects of a subject, and is "the recipient of burning enjoyment/jouissance" (Paccaud-Huguet 288). It is through the letter that "a fragment of the speechless Real can accidentally be written" - for in the conception of the signifier that Lacan developed after 1971 (especially after the publication of the article "Lituraterre"), the dimension of the Real is present in the Symbolic. The letter in the Lacanian sense could be defined as "a non-semantic bunch of graphemes and phonemes resisting the movement of the signifying chain, addressed to no-one, representing jouissance for another signifier" (Paccaud-Huguet 288). The letter is a useless leftover, an object that comes in excess of meaning: the homophony between "a letter, a litter", pointed out by Joyce and taken up by Lacan in his "Seminar on the "Purloined Letter"' (Lacan 1966, 41), acquires a new resonance in the perspective opened by "Lituraterre". Like "lalangue", the linguistic reserve from which it is drawn, the letter is both singular and universal: it is private, and yet a recognizable mark that may be shared with others through a medium like poetry or literature ${ }^{7}$. It is by essence paradoxical, being situated on the "littoral" between irreconcilable entities, knowledge and jouissance - between the Symbolic and the Real. Its arabesques flourish, to use Virginia Woolf's words, "round a centre of complete emptiness" (Woolf 193), an idea which Lacan formalized by saying that its lines follow "the edge of the hole in knowledge", or by the metaphor of writing as what "furrows" the 
signified in the Real' ${ }^{8}$. To go back to our example from Tess of the d'Urbervilles: the repetition of graphemes and phonemes blocks the movement of the signifying chain and delays the emergence of meaning; it produces a blind spot in signification, a void against which writing becomes resonant. "The artist should let go of sense in favour of sound [...] a resonant silence is needed to awaken the echoes asleep in the memory of a language" (Paccaud-Huguet 289). When the artist succeeds in that task, the effect is one of pure pleasure/enjoyment, which may be shared by all readers.

Once we accept the idea that the letter hollows out the surface of a text, that it is "a receptacle always ready to contain jouissance" (Lacan 2001, 19), we can understand that it has the capacity to pacify the lethal jouissance at work in tragedy: "the littoral state of the signifier enables it to both contain and constrain the silence of the drives towards the primordial object, which is also the drive towards annihilation" (Paccaud-Huguet 289). The "murder of the Thing", normally achieved by the metaphoric function of language, and which somehow fails in the tragic universe where the word is made flesh, may be reactivated through the agency of the letter: for the letter as meaningless "litter" opens up a gap in language, a rift between signs and their referents (or between signifier and signified), and helps to contain/constrain the destructive drives that turn Tess's body into a readable "tex". The excess of meaning is corrected, the signifier is no longer incarnated, the Thing is out of reach. The letter as "littoral" hems the Real and prevents its deadly confusion with the Symbolic. Viewed in that light the "murder of the Thing" is certainly more a gain than a loss: for though we are somehow "purged" of our passions by the barring of jouissance, the letter allows us to enjoy a few fragments of it. The red "spot" that ear-marks Tess turns into the "spots of froth" travelling past the swift moonlit stream in the valley of the Froom ${ }^{9}$ - a metatextual representation of the little "surplus enjoyment" afforded by the literary text. Paradoxically, the letter vivifies because it murders the Thing.

The poetic quality of Hardy's prose has often been brought to the fore ${ }^{10}$. Meaning flickers all along the phonematic chains that run through the novels. The "stone" paradigm unfolds from the very first pages to the last in Tess of the d'Urbervilles, with the play on words like "stone", "bone", "skeleton" or "skillenton", "tons", "Wintoncester", "wanton", "went on" - "on" being the first word of the novel, and the last. In The Mayor of Casterbridge, the text seems to be engendered through a paronomasia that carries us from "reverberation" to "reverie", "rivetted", "revel", "revelation", "rival", "rivalry", "revelry", while "corn" rhymes with "unicorn" and "horn", "weir" with "hear" and "ear". In The Woodlanders, the signifier "dress" sends poetic resonances that reverberate all through the novel: it is echoed by "tress", "mistress", "actress", "distress", "address", "press", "empress", etc. In The Return of the Native, the last four letters of "return" become detached from the title to form "urn", a key-signifier in the novel, whose letters proliferate in other major signifiers that are repeated insistently ("burn", "turn"), while the phonemes of "urn" are heard in "fern", "earn", and "learn" etc. I would like to go further and show another way in which the letter may produce a "hole-effect" (as well as a "meaning-effect"11). I will take an example ${ }^{12}$ from The Woodlanders, and focus on a sentence in the key-scene when Fitzpiers discovers what he believes to be the mangled form of his wife caught in a mantrap:

"O my own - my darling - o cruel heaven - it is too much this!" he cried, writhing and rocking himself over the sorry accessories of her he deplored". (Hardy 1985, 268) 
11 One feels the stinging poignancy of Fitzpiers's despair as the text proceeds through paronomasia ("cruel" /cried", "cried" /writhing" ...), repeating consonants (/r/ mostly, also $/ \mathrm{k} /$ ) as well as the letters "o" and " $\mathrm{r}$ " in "rocking", "sorry", "accessories", "deplored". "Sorry" is followed by "accessories", which (nearly) takes up the same letters/phonemes. But why should the repetition make us sense the horror of the "thing" caught in the trap? Could it be because the repeated phonemes sound against some resonant silence? Indeed as we reach the end of the sentence the letter " $r$ " turns mute in "her he deplored": it is mute in "her", elided in "he" (where the final "r" of "her" has been crossed out), and silent in "deplored". The textual voice opens a void, a core of silence that hollows out the sentence and makes resonance possible - for resonance always takes place in a vacuum. The function of the letter here is to "edge" the void of the Real (as Lacan has argued), to delineate a "centre of complete emptiness". The blind spot lodged in a silent letter both contains the horror (it allows the unspeakable Real to be written), and constrains it (it puts limits round it).

12 A similar "hole-effect" is produced in the last chapter of Tess of the d'Urbervilles. The ear cannot fail to notice the recurrence of the personal pronoun "it": first "it" refers to the prison; then, "it" refers to the ugly flat-topped octagonal tower that rises above the prison; lastly, through further reduction, the antecedent of "it" becomes "a tall staff", then "a black flag":

Upon the cornice of the tower a tall staff was fixed. Their eyes were rivetted on it. A few minutes after the hour had struck something moved slowly up the staff, and extended itself upon the breeze. It was a black flag. (Hardy 1988, 384)

The reader who is prepared to lend an ear to this text will go one step further: for he soon realizes that the phonemic pair /it/ is scattered all over the text, having crept into a great number of signifiers: "city", “captivity”, "irregularities", “wicket", "rivetted on it", "minut es". The last chapter is literally overrun by the phonemes of "it", which are also found in "capital", "market", "pitilessly", "spiritualized", "summit", "unlimited" (my italic). If we place the vowel and the consonant of "it" in reverse order, we find that the phonemic pair /ti/ also proliferates in the chapter: "city" (seven occurrences), "pitilessly", "beautiful", "captivity", "irregularities", "beauty" (two occurrences). One thing is surprising: "it" is totally absent in the last paragraph. The sudden disappearance of a phonemic/graphic pair that has haunted the chapter so far is rather puzzling. All the more so as it occurs in a paragraph which makes us hear the deadly silence prevailing in the scene ("the two speechless gazers bent themselves down [...] and remained thus a long time, absolutely motionless: the flag continued to wave silently"). A closer look at the letter of the text reveals the unobtrusive presence of the graphic pair, almost hidden in "time", "motionless", "continued". But the phonemes of "it" have been hushed (except perhaps in "continued"). The two letters are mute in "motionless", where " $t$ " is pronounced /sh/ and "i" is not sounded. As in The Woodlanders, a void is opened by the textual voice, a core of silence hollows out the sentence at the very point where a lack is marked in the text by the repetition of negative prefixes or suffixes: "unknowing", "speechless", "motionless". The void is also represented graphically by the space between verb and adverb in "slept on" and "went on" (the final words of the novel) - two spaces that place the letter " $t$ " on the edge of a void, thus rending asunder the solid mass formed by the letters of "stone" in this chapter. As I have argued elsewhere (Ramel 107), the first words of the chapter ("The city of Wintoncester") form a loop with the last words ("went on"), with perhaps an echo of the lines from King Lear quoted by Hardy in his preface ("as 
flies to wanton boys are we to the gods", my italics), as though to repeat the circular motif introduced by the reference to Stonehenge, and to suggest that life has become petrified. The rift in "went on" and the blind spot produced by the reduction of the phonemic pair / it/ to silent letters produce a "hole-effect": a void which makes the poetic voice audible in the silence of the literary text. The poetic letter gives life by rending asunder the colossal monolith of tragic jouissance.

\section{BIBLIOGRAPHY}

Bronfen, Elisabeth, "Pay as You Go: on the Exchange of Bodies and Signs", ed. Margaret R. Higonnet, The Sense of Sex: Feminist Perspectives on Hardy, Urbana: U of Illinois P, 1993, 66-86.

Escuret-Bertrand, Annie, “Tess des d'Urberville: le Corps et le Signe”, Cahiers Victoriens et Édouardiens, 12 (1980): 85-136.

Escuret-Bertrand, Annie, “L'œuvre romanesque de Thomas Hardy (1840-1928): lecture”, unpublished PhD Diss., Montpellier, 1983.

Garson, Marjorie, Hardy's Fables of Integrity: Woman, Body, Text, Oxford: Clarendon Press, 1991.

Hardy, Thomas, The Return of the Native (1878), Oxford: OUP, The World's Classics, 1990.

Hardy, Thomas, The Mayor of Casterbridge (1886), Oxford: OUP, The World's Classics, 1987.

Hardy, Thomas, The Woodlanders (1887), Oxford: OUP, The World's Classics, 1985.

Hardy, Thomas, Tess of the d'Urbervilles (1891), Oxford: OUP, World's Classics, 1988.

Hillis Miller, Joseph, Fiction and Repetition, Cambridge (Mass.): Harvard University Press, 1982.

Lacan, Jacques, “Lituraterre”, Autres Écrits, Paris: Seuil, 2001.

Lacan, Jacques, Écrits, Paris: Seuil, 1966.

Paccaud-Huguet, Josiane, "Psychoanalysis after Freud", Literary Theory and Criticism (an Oxford Guide), ed. Patricia Waugh, Oxford: OUP, 2006, 280-297.

Ramel, Annie, "The Other in Tess of the d'Urbervilles: the alter/altar of sacrifice", RANAM, 36 (2004): 99-109.

Tanner, Tony, "Colour and Movement in Tess of the d'Urbervilles", The Tragic Novels: a Selection of Critical Essays, ed. R. P. Draper, London: Casebook Series, 1975, 182-208.

Woolf, Virginia, To the Lighthouse (1927), London: Flamingo, 1995.

\section{NOTES}

1. Paraphrasing Lacan, who has argued that a letter always arrives at its destination (Lacan, Écrits 41), we could say that one way or the other, letters in Hardy's fiction always achieve their goal: they make sure that the worst happens. 
2. The letter here is some kind of rubbish - which cannot fail to remind us of the equation made by Joyce/Lacan between "a letter, a litter" (Lacan 2001, 11).

3. See Escuret 1983, 1980 (85-136). On the theme of "grafting" or "imprinting" on Tess's body, see of course Hillis Miller 122.

4. That perspective is radically different from that of Derrida, for whom "writing in the common sense is the dead letter, it is the carrier of death. It exhausts life" (quoted by Bronfen, 69). For Lacan, language, whether written or oral, is "the murder of the thing", it spells the absence of the thing (or the referent), but such death is life-giving: the process known as the "paternal metaphor" prohibits jouissance and thereby achieves symbolic castration. When symbolic castration dysfunctions, the jouissance of the Other becomes boundless, and spells disaster - for the subject - in psychosis, or in tragedy. For approaches different from mine (but convergent on many issues), see Elisabeth Bronfen and Marjorie Garson.

5. We note the same confusion in Racine's Iphigenia between symbolic and real blood: "Vous armez contre Troie une puissance vaine / Si dans un sacrifice auguste et solennel / Une fille du sang d'Hélène / De Diane en ces lieux n'ensanglante l'autel" (Iphigénie I 1).

6. In lacanian clinical psychoanalysis, that "turning back" ("rebrousse") enacts the passage from "symptom" to "sinthom".

7. The use of the letter made by poets "intimates that what comes first is our contact with a primordial linguistic mode called 'lalangue"' (Paccaud-Huguet 188). "Lalangue" is produced by our encounter with the maternal language, it is the language of affects, a pre-Symbolic linguistic form loaded with a palpitating substance of enjoyment/jouissance. There is no letter without "lalangue", argues Lacan, for "lalangue" is repressed (by language), and what returns in a crystallized form is precisely the letter. The letter associates the signifier and jouissance, "lalangue" associates language and jouissance.

8. "Lituraterre": "Le bord du trou dans le savoir, voilà-t-il pas ce qu'elle dessine" (14), "l'écriture est dans le réel le ravinement du signifié" (17).

9. In that scene, Angel, who is sleep-walking, is seen tottering on the brink of the river with Tess in his arms. Note the insistent repetition - the redundancy - of the letter/litter "o" in the passage: "Midnight came [...] there was nothing to announce it in the valley of the Froom" (242), "the spot was lonely [...] the swift stream raced and gyrated under them, tossing, distorting, and splitting the moon's reflected face. Spots of froth travelled past [...]" (244).

10. See Cahiers Victoriens et Édouardiens, 2009 (69), "L'écriture de Thomas Hardy: entre fiction et poésie", acts of the 2007 Thomas Hardy conference in Lyon.

11. Cf Lacan, "La poésie [...] qui est effet de sens, mais aussi effet de trou". Ornicar $n^{\circ}$ 17-18, pp. 21-22.

12. Another striking example, given by my colleague Michel Cusin (in an unpublished seminar held in Lyon in 2008), shows that such "hollowing out" of a text may occur in all languages, not only in English. The passage is from Bossuet's "Oraison funèbre d'Henriette d'Angleterre": "Ô nuit désastreuse! ô nuit effroyable, où retentit tout à coup, comme un éclat de tonnerre, cette étonnante nouvelle: Madame se meurt! Madame est morte!". The obsessive repetition of / $t$ / stumbles over a mute " $t$ ", the one in "meurt", which introduces a core of silence into the sentence. The "hole-effect" is remarkable. 


\section{ABSTRACTS}

The epigraph to Jude the Obscure announces that "the letter killeth". If we take the word "letter" as meaning "a missive", we find that in Hardy's novels it is often the letter that kills. More importantly, it is often because the characters' words are taken to the letter that they meet their doom. A peculiar characteristic of language in Hardy's tragic universe is that the signifier is incarnated in the Real of human bodies-while human bodies are "intextuated". There is too much meaning in the diegesis.

The poetics of Hardy's text corrects this excess in meaning, and thus pacifies the lethal jouissance that spells destruction for the protagonists. The flicker of meaning produced by the poetic play on language dissolves the coagulation that in the diegesis conflates signifier, signified and referent in a solid mass. It brings air to the textual fabric. It is through the textual voice-the voice that wends its way through the gaps and cracks of the text, producing "hole-effects" by the play on the materiality of the signifier and on the Letter-that the voice of the demanding Other of tragedy may be silenced, and that the death drive may turn into a life drive. Indeed, on the textual level, the Letter vivifies.

L'épigraphe en tête de Jude the Obscure annonce que «la lettre tue ». Si on prend le mot "lettre » dans son sens épistolaire, on s'aperçoit que dans les romans de Hardy c'est en effet souvent la lettre qui tue. Plus fondamentalement, c'est parce que les paroles des personnages sont prises à la lettre que ceux-ci sont emportés par un destin funeste. Une caractéristique particulière du langage dans l'univers tragique de Hardy est que le signifiant s'incarne dans le Réel des corps - cependant que les corps « s'intextuent ». Il y a trop de sens dans la diégèse.

Le poétique dans les textes de Hardy corrige cet excès de signification, et pacifie la jouissance létale qui cause la destruction des protagonistes. Il fait vaciller le sens et par là dissout cette coagulation qui dans la diégèse confond signifiant, signifié et référent en une masse compacte. Il permet la respiration du texte. C'est par la voix textuelle - la voix qui se faufile dans le texte et y met des points de silence, provoquant des «effets de trous» par le jeu sur la matérialité du signifiant et sur la Lettre - que la voix de l'Autre insatiable de la tragédie peut être réduite au silence, et que la pulsion de mort peut se « rebrousser » en pulsion de vie. Au niveau textuel, c'est bien la lettre qui vivifie.

\section{INDEX}

Mots-clés: roman, lettre, langage, poétique, silence, psychanalyse, Lacan (Jacques), tragédie Keywords: letter, novel, language, poetics, silence, psychoanalysis, Lacan (Jacques), tragedy oeuvrecitee Tess of the d'Urbervilles, Jude the Obscure, Mayor of Casterbridge (The), Woodlanders (The), Return of the Native (The) 
AUTHOR

ANNIE RAMEL

Université Lumière-Lyon 2

Professeur émérite 